\title{
EVALUATION OF SOME TURF IRRIGATION SPRINKLERS UNDER DEFICIT IRRIGATION LEVELS
}

\section{Ahmed R. Eid ${ }^{1}$, Mohamed Y. El Ansary ${ }^{2}$, Abousrie A. Farag ${ }^{3}$, and Wael M. Sultan ${ }^{4}$ \\ ABSTRACT}

Several types of turf irrigation equipment are available to best meet the landscape requirements: from long range sprinklers that throw water for more than twenty meters to a small sprayer that splash water for 2-5 meters or less. So, selecting the right equipment is an important part of landscape irrigation. Uniformity of water distribution, water use rationalization and total costs are the major concerns for design and management of turf irrigation systems in Egypt. Therefore, the aim of this research was to evaluate the performance of Spray sprinklers PS and Rotator sprinklers MP on the distribution pattern uniformity of soil moisture content and water use efficiency of turf grass (Paspalum 10), under deficit irrigation management.

The field experiment was executed in sandy soil, at the Up Town Cairo compound, Mukattam city, Cairo governorate, during 2017-2018 seasons. The results indicated that

- Water distribution uniformity $D U_{l q}$ for the rotator type sprinkler MP was higher than that for the spray type sprinkler PS, while the coefficient of uniformity (CU) was similar for the two types of sprinklers.

- The average soil moisture content for MP sprinkler after irrigation run was $7 \%$ higher than that for PS sprinkler under all tested deficit irrigation levels.

- The grass growth rate and water use efficiency for MP sprinkler were $12.9 \%$ and $13.3 \%$ higher than those for PS sprinkler respectively. As well as, using MP rotor sprinkler can save $20 \%$ of water compared with full irrigation using PS sprayers with no effect on grass growth rate or water use efficiency.

Keywords: landscape irrigation, grass, turf, sprinkler irrigation, evaluation, and deficit irrigation.

1- Post graduate student.

2- Prof. of Agric. Eng., Faculty of Agric., Benha Univ.

3- Lecture of Agric. Eng., Faculty of Agric., Benha Univ.

4- Senior Res., Agric. Eng. Res. Inst.

Misr J. Ag. Eng., April 2019 


\section{INTRODUCTION}

7 he rapid increase in population is considering one of the most critical problems, which hinders the development process in Egypt. Landscape projects mainly grow when the rates of population and new cities constructions increase. The available water should be used economically for future horizontal expansion, especially when the national demand is directed to optimize the water usage. The main sources of landscape water waste are: poor irrigation scheduling, inefficient irrigation systems and practices, and fixed notions about what constitutes an attractive and functional landscape. Various conservation measures have been proposed and to counter these wasteful sources such as (soil and water analysis, proper plant and efficient irrigation), landscaping with native vegetation, improvements in irrigation technology including the use of moisture sensors and evapotranspiration (ET) data, reuse waste water for irrigation purposes (Waltz, 2007).Irrigation systems management is very important concern in Egyptian water conservation strategy due to the shortage in water resources. The use of modern irrigation system such as sprinkler irrigation increases the water use efficiency. Sprinkler irrigation system is one of these techniques that has already been using in landscape because it can save irrigation water of about $42 \%$ (Sultan et al, 2013).It could efficiently manage any irrigation system including sprinkler by applying the right amount of water in suitable time for plant, and taking into consideration some variables such as site, soil, plant and economic value of the system, in addition to how to overcome maintenance problems. (Ameer et al, 2009).Egypt is located in warm-season areas, so they use warm-season grass like Paspalum vaginatum, Paspalum notatum and Bermuda grass (Huang, 2006).

\section{The main objectives of this study were:}

Comparing between PS spray sprinklers and MP rotator sprinklers by studying:

- The performance of the two types (MP and PS) sprinklers under site conditions.

- Effect of deficit irrigation treatments for full (F100\%), deficit irrigation (D80\%) and deficit irrigation (D60\%) of water requirement on soil moisture distribution pattern and uniformity. 
- Effect of deficit irrigation treatments on the rate of grass growth and its water use efficiency.

\section{MATERIALS AND METHODS}

Field experiment was carried out at the Up Town Cairo compound, Mukattum city, Cairo Governorate, Egypt (30 1'18.28"N, 31 $\left.{ }^{\circ} 18^{\prime} 9.51 " \mathrm{E}\right)$, during 2017-2018 season. Soil physical and chemical analysis indicated that soil of experimental area was sand with $\mathrm{PH}$ of 8.4, organic matter of $10 \%, \mathrm{CaCO} 3$ of $1.2 \%$, and $\mathrm{C}: \mathrm{N}$ ratio of 32.3 . The source of irrigation water was domestic water with total salinity of 46.4 PPM and PH 7.37. The tested grass variety was Paspalum 10.

\section{The experimental irrigation equipment:}

Electric driven centrifugal pumping unit of $50 \mathrm{~m}^{3} / \mathrm{h}$ flow rate at $0.5 \mathrm{MPa}$ maximum operating pressure and $85 \%$ efficiency, it was used to irrigate the all landscape areas in the compound. Mainline pipes was made of $75 \mathrm{~mm}$ diameter UPVC PN10, sub mainline pipes were made of $50 \mathrm{~mm}$ diameter UPVC PN10 and. The lateral line pipes was made of $32 \mathrm{~mm}$ diameter UPVC PN10, and connected on the right and left of the sub main pipe lines to deliver water to the sprinklers attached on it. The control head of the experimental area consisted of electrical solenoid valves connected with manual valve, pressure gages, a screen filter and a control panel.

\section{Specification of the two studied sprinkler types}

1. Spray type sprinklers (Hunter-PS 8A): The flow rate was $0.2 \mathrm{~m}^{3} / \mathrm{h}$ at $0.25 \mathrm{MPa}$ operating pressure which gave $34.7 \mathrm{~mm} / \mathrm{h}$ precipitation rate, under square arrangement of $2.4 \mathrm{~m} \times 2.4 \mathrm{~m}$ spacing between sprinklers.

2. Rotator type sprinklers (MP1000): The flow rate was $0.08 \mathrm{~m}^{3} / \mathrm{h}$ $0.25 \mathrm{MPa}$ operating Pressure that gave $13.8 \mathrm{~mm} / \mathrm{h}$ precipitation rate under square arrangement of $2.4 \mathrm{~m} \times 2.4 \mathrm{~m}$ spacing between sprinklers.

\section{Deficit irrigation treatments:}

To evaluate the two types of sprinkler from water saving point of view, the evaluation study had done under three levels of irrigation i.e. full irrigation (F100\%), deficit irrigation (D80\%) and deficit irrigation (D60\%) of irrigation requirements as (D80\%) and (D60\%) respectively (fig. 1). 


\section{Methodology:}

- Performance evaluation using catch can test to evaluate the flow rate, distribution uniformity and coefficient uniformity of sprinkler systems. The tests involved setting out catch cans on square arrangement $60 \times 60 \mathrm{~cm}$ and running the system for 15 minutes which was an enough time to collect measurable amounts of water in the catch cans, (fig2).

According to Merriam and Keller, 1978 and Ismail, 2009, the evaluation parameters included the following:

$$
\text { Precipitation rate }(\mathbf{P R})=\frac{Q \times 1000}{A} \quad \mathrm{~mm} / \mathrm{h}
$$

Where: (Q) Sprinkler flow rate $\mathrm{m}^{3} / \mathrm{h}$, and

(A) Area wetted by sprinkler (S x L).

Irrigation time $(\mathbf{T})=\frac{E T o \times K c}{P R \times E a}$

Where: (ETo) Evapotranspiration, mm/day, (calculated by ClimWAT software). (fig.3).

(Kc) Crop factor, dimensionless, (calculated by CropWAT software

(PR) Precipitation rate, $(\mathrm{mm} / \mathrm{h})$ and (Ea.) Irrigation efficiency $(\%)$

Distribution uniformity (DU): Describes how evenly water is applied over the irrigated area, the uniformity of sprinkler irrigation is a central design goal

$$
\boldsymbol{D} \boldsymbol{U}=\frac{\text { Average of the low quarter }}{\text { Average of all catches }}
$$

Christiansen Uniformity Coefficient (CU): used in agricultural sprinkler uniformity assessment and is expressed, It is the most accepted way for estimating irrigation uniformity (fig3).

$$
\boldsymbol{C U} \%=100 \times\left(1-\left(\frac{\sum_{1}^{n}\left|X-X^{\prime}\right|}{n X^{\prime}}\right)\right.
$$

Where CU= Christiansen Uniformity Coefficient (\%).

$\mathrm{X}=$ individual catch can measurement $(\mathrm{mm})$.

$\mathrm{X}^{\prime}=$ average of application over all catch cans (mm). 


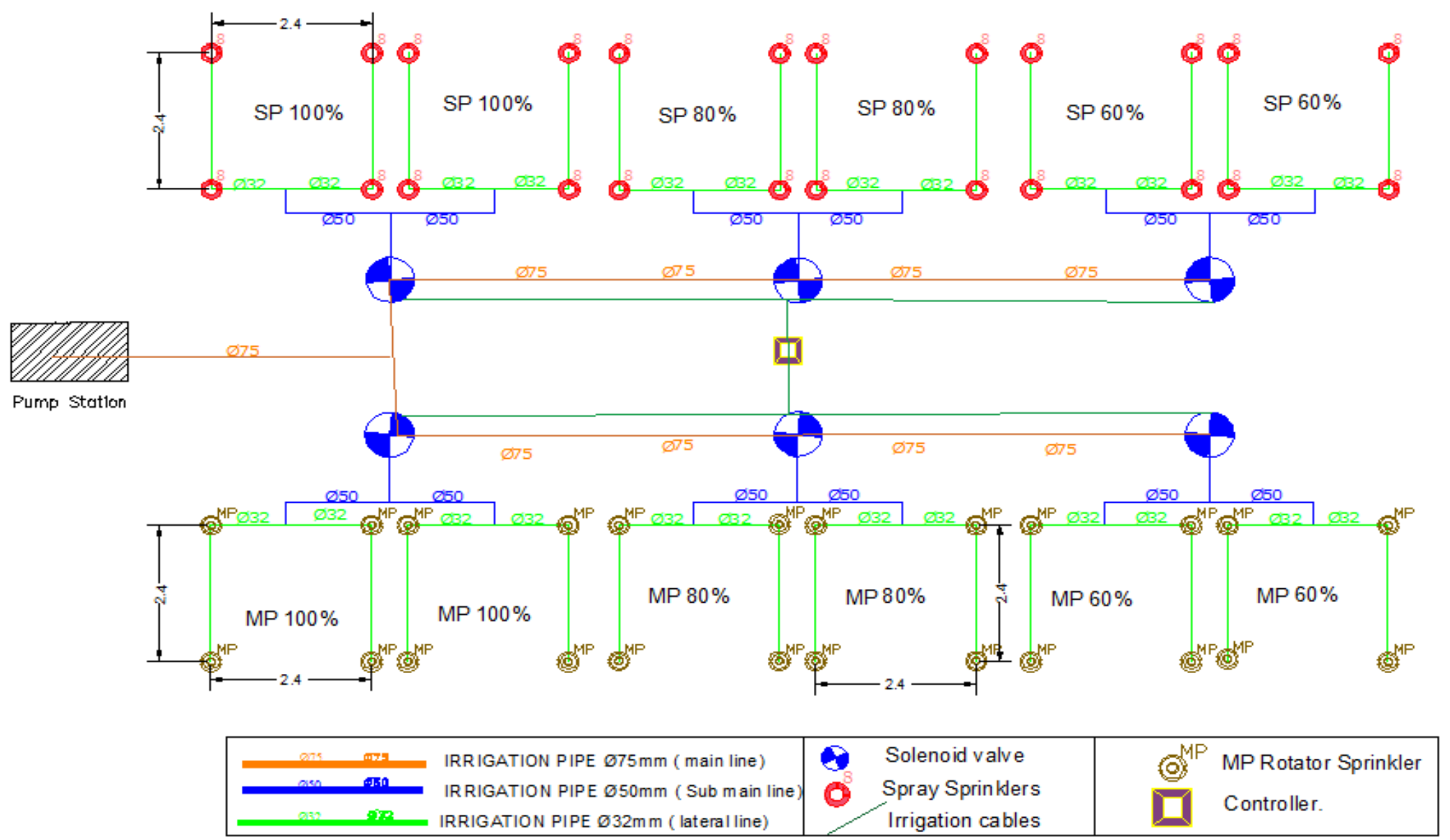

Fig. (1) Network layout for the experiment. 


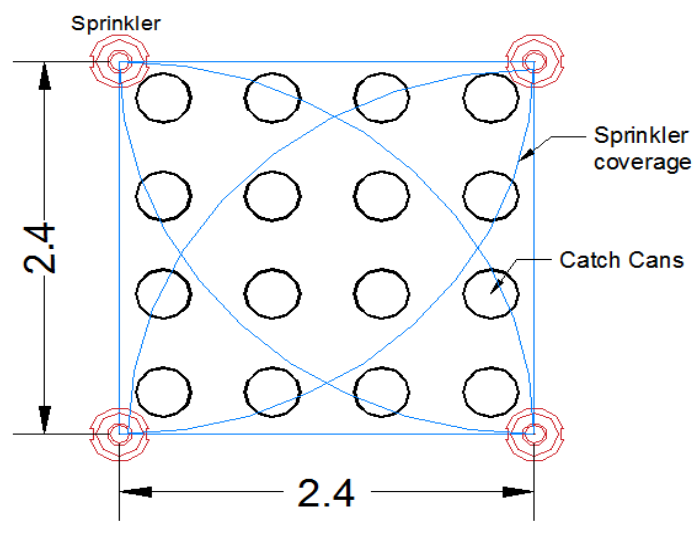

Fig (2): Catch cans layout.

\begin{tabular}{|c|c|c|c|c|c|c|c|c|}
\hline \multicolumn{6}{|c|}{ (6) Monthly ETo Penman-Monteith - D:ICAIRO.pen } & ㅁ & 回 $\mathbb{X}$ & \\
\hline \multicolumn{5}{|c|}{ Country Location 3} & \multicolumn{4}{|c|}{ Station CAIRO } \\
\hline Altitude & $74 \mathrm{~m}$. & \multicolumn{3}{|c|}{ Latitude $\longdiv { 3 0 . 1 3 } \quad \sqrt { N }$} & \multicolumn{3}{|c|}{ Longitude $\longdiv { 3 1 . 4 0 } { } ^ { \circ } \mathrm { E }$. } & \\
\hline \multirow[t]{2}{*}{ Month } & Min Temp & Max Temp & Humidity & Wind & Sun & Rad & ETo & \\
\hline & ${ }^{\circ} \mathrm{C}$ & ${ }^{\circ} \mathrm{C}$ & $\%$ & $\mathrm{~km} / \mathrm{day}$ & hours & $\mathrm{MJ} / \mathrm{m} \mathbf{\mathrm { y }} / \mathrm{day}$ & $\mathrm{mm} /$ day & \\
\hline January & 9.0 & 18.8 & 54 & 328 & 7.5 & 13.1 & 3.26 & \\
\hline February & 9.8 & 20.5 & 47 & 363 & 8.2 & 16.1 & 4.27 & \\
\hline March & 11.7 & 23.4 & 41 & 397 & 9.0 & 19.9 & 5.67 & \\
\hline April & 14.7 & 28.4 & 32 & 389 & 9.7 & 23.2 & 7.59 & \\
\hline May & 17.5 & 32.0 & 29 & 397 & 10.7 & 25.8 & 9.06 & \\
\hline June & 20.4 & 34.2 & 31 & 372 & 11.8 & 27.7 & 9.54 & \\
\hline July & 21.7 & 34.4 & 38 & 320 & 11.7 & 27.3 & 8.70 & \\
\hline August & 21.9 & 33.9 & 43 & 302 & 11.3 & 25.7 & 7.89 & \\
\hline September & 20.4 & 32.6 & 45 & 320 & 10.5 & 22.6 & 7.18 & \\
\hline October & 17.9 & 29.6 & 46 & 328 & 9.6 & 18.5 & 5.96 & \\
\hline November & 13.8 & 24.7 & 57 & 285 & 8.4 & 14.4 & 3.84 & \\
\hline December & 10.3 & 20.2 & 56 & 320 & 7.1 & 11.9 & 3.23 & \\
\hline Average & 15.8 & 27.7 & 43 & 343 & 9.6 & 20.5 & 6.35 & \\
\hline
\end{tabular}

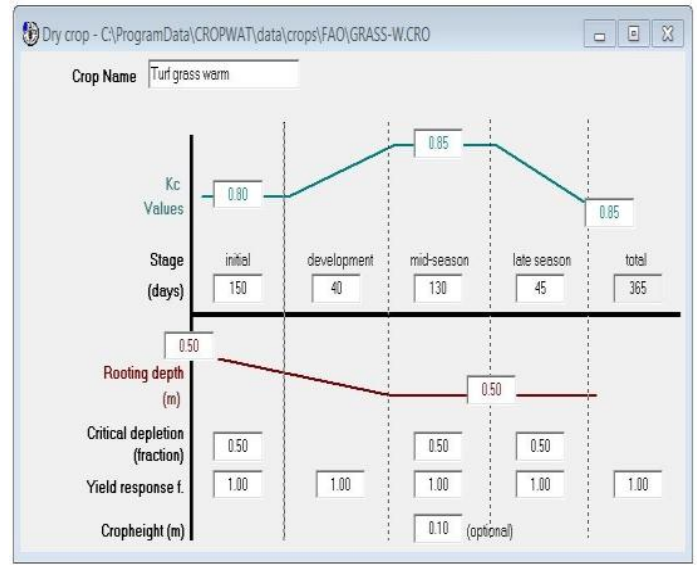

Fig (3): Calculate ETo and Kc by ClimWAT and CropWAT soft wares.

- Measuring of soil moisture content in 10 to $20 \mathrm{~cm}$ layer depth before irrigation and after one hour from the end of irrigation (FAO, 1985) by using a Time Domain Reflect meter (TDR). The measurements carried out for the three deficit irrigation treatments. $\mathrm{F} 100 \%$, D80\%, and D60\% of the total irrigation water requirements, and analyses of moisture distribution patterns were done by Golden surfer software.

- Measuring the grass growth yield and its water use efficiency under deficit irrigation: Irrigate the grass with deficit irrigation for each sprinkler, each area of the three deficit irrigation treatments was divided to four replicates with unification of all other parameters like fertilization and timing of grass cutting. The growth duration was two 
weeks before each grass cutting. The grass cutting was carried out by mower and the harvested grass was weighed by a digital balance as an indication for grass growth rates.

\section{RESULTS AND DISCUSSIONS}

\section{Evaluation of sprinklers performance:}

1. The precipitation rate (PR) tests: Fig (4) shows the perception rate for MP and PS sprinklers along catch can line. The average precipitation rate PR were 35.37 and $16.43 \mathrm{~mm} / \mathrm{h}$ PS and MP sprinklers respectively. So the perception rate for PS sprinkler was higher than that for MP sprinkler, therefore irrigation time by using PS sprinkler was less than MP sprinkler duration. The highest value of precipitation rate was at 2 bar and 2.8 bar for SP and MP respectively (Hunter 2012).

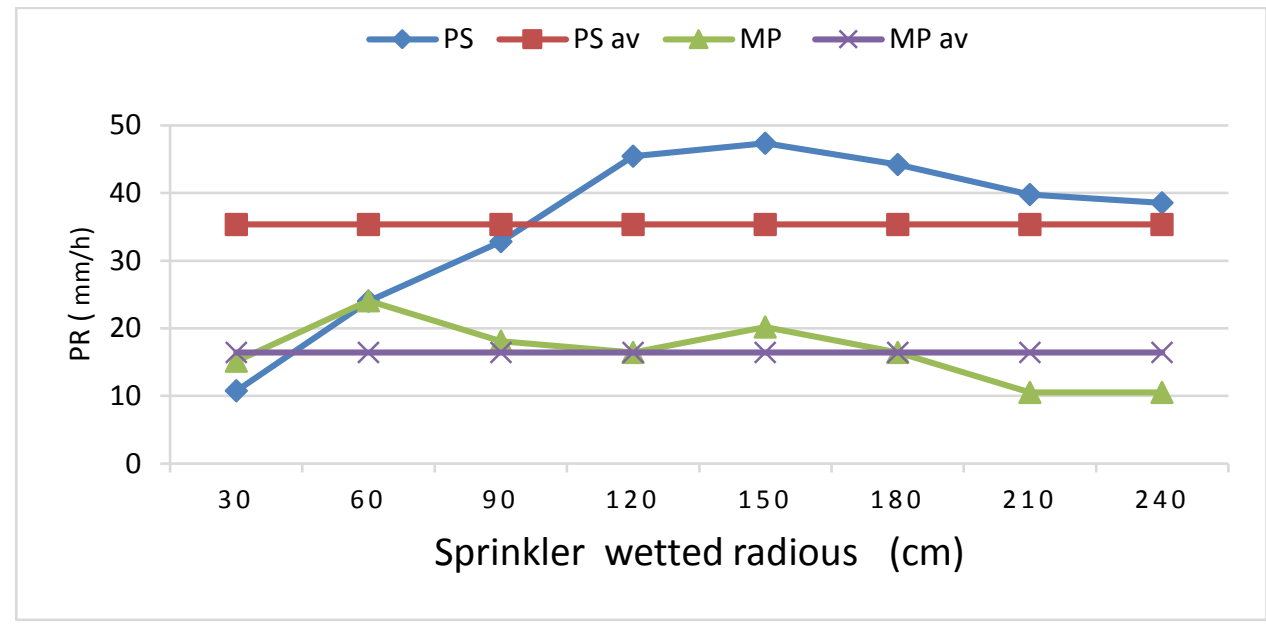

Fig (4): Water precipitation rates pattern for PS and MP.

2. Water distribution uniformity (DUlq and CU): The low quarter water distribution uniformity DU $\mathrm{U}_{\mathrm{lq}}$ for MP and PS sprinklers by using catch cans test were $82 \%$ and $77 \%$ respectively. While the uniformity coefficient (CU) for both MP and PS sprinklers were similar (about 98\%). So, both sprinklers gave good water distribution uniformity, but the performance of MP sprinklers was better than PS especially in the areas received low quarter amounts of water.

II. Sprinklers type effect on soil moisture content under deficit irrigation: The values of soil moisture content for the experimental site 
before irrigation were between 15.4 and $15.6 \%$. The ETc during the experiment duration was $7.81 \mathrm{~mm}$ and water requirement (WR) was $9.19 \mathrm{~mm} / \mathrm{m}^{2} /$ day, so full irrigation duration for PS and MP sprinkler were 16 and 40 minutes respectively.

Figures $(5,6,7$ and 8$)$ indicate the distribution patterns of soil moisture content after irrigation by each sprinkler under three irrigation levels F100\%, D80\%, and D60\%., For full irrigation (F100\%) from irrigation requirement, the average soil moisture content for MP and PS sprinklers were $31.68 \%$ and $29.61 \%$ and the corresponding DU values were $88.47 \%$ and $82.85 \%$ respectively, while ,. CU was 98.7 for both types of sprinklers. For deficit irrigation (D80\%) the average soil moisture content for MP and PS sprinklers were $27.38 \%$ and $26.33 \%$ respectively. The corresponding DU values were $86.35 \%$ and $80.73 \%$ respectively, while $\mathrm{CU}$ was 98.32 for both types of sprinklers. For deficit irrigation (D60\%) the average soil moisture content for MP and PS were $22.2 \%$ and $21.8 \%$ respectively. Correspondingly, the DU values were $84.2 \%$ and $78.6 \%$ respectively. The $\mathrm{CU}$ values were around $98.18 \%$ for the two types of sprinklers.

\section{Effect of deficit irrigation on grass growth and (WUE) under the} two types of sprinklers: Figures (9 and 10) show the rate of grass growth (cutting grass weight $\mathrm{g} / \mathrm{m}^{2}$ ) and water use efficiency (WUE) under different deficit irrigation treatments for both sprinklers.

The average of grass growth weight obtained from full irrigation (F100\%) treatments were $106.4 \mathrm{~g} / \mathrm{m}^{2}$ and $92 \mathrm{~g} / \mathrm{m}^{2}$ for MP and PS sprinklers respectively. For deficit irrigation (D80\%) the average grass growth weights were 73.25 and $62 \mathrm{~g} / \mathrm{m}^{2}$ for MP and PS respectively, while for deficit Irrigation (D 60\%) the average grass weights for MP and PS sprinklers were $41.46 \mathrm{~g} / \mathrm{m}^{2}$ and $34.38 \mathrm{~g} / \mathrm{m}^{2}$ respectively. These results consistent to (Sultan, et al 2013).

The average WUE for full irrigation (F100\%) treatment were 142.78 $\mathrm{g} / \mathrm{m}^{3}$ and $124.68 \mathrm{~g} / \mathrm{m}^{3}$ for MP and PS sprinkler respectively. For deficit irrigation (D80\%) average WUE were 124.15 and $106.56 \mathrm{~g} / \mathrm{m}^{3}$ for MP and PS respectively, while for deficit irrigation (D60\%) it was 94.22 $\mathrm{g} / \mathrm{m}^{3}$ and $78.13 \mathrm{~g} / \mathrm{m}^{3}$ for MP and PS respectively.

It could be observed that using MP rotor sprinklers with deficit irrigation (D80\%), can save $20 \%$ of water without harm effect on grass 
growth, since it was only $19 \%$ less grass growth than that obtained from full irrigation (F100\%) applied by PS sprayers. Moreover, using MP rotor sprinkler with $80 \%$ deficit irrigation produced same amount of grass per cubic meter of water exactly as that produced from $100 \%$ full irrigation applied by PS sprayer.

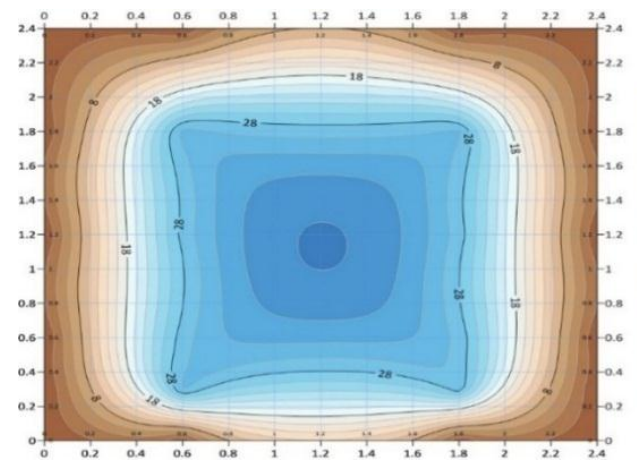

PS

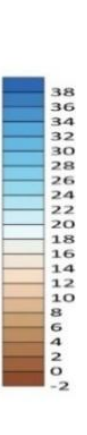

Fig (5): Soil moisture content after full irrigation (F100\%).

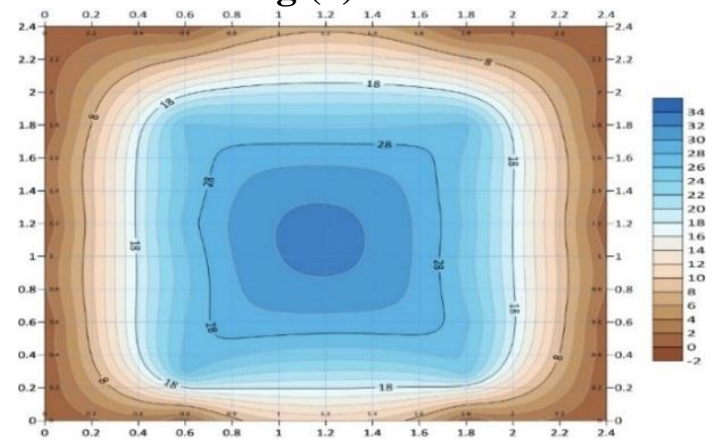

PS

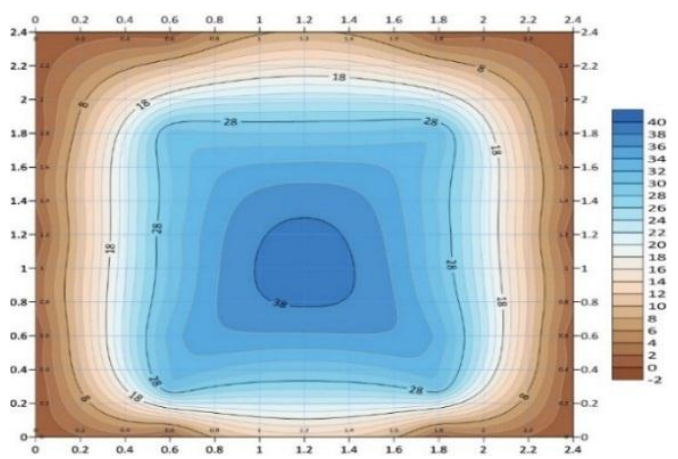

MP

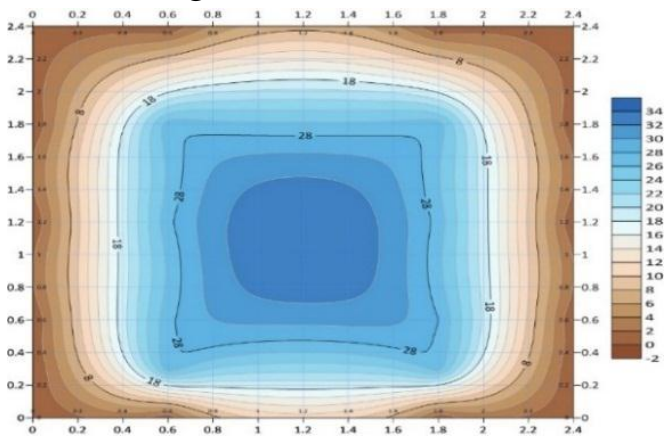

MP

Fig (6): Soil moisture content after deficit irrigation (D80\%).
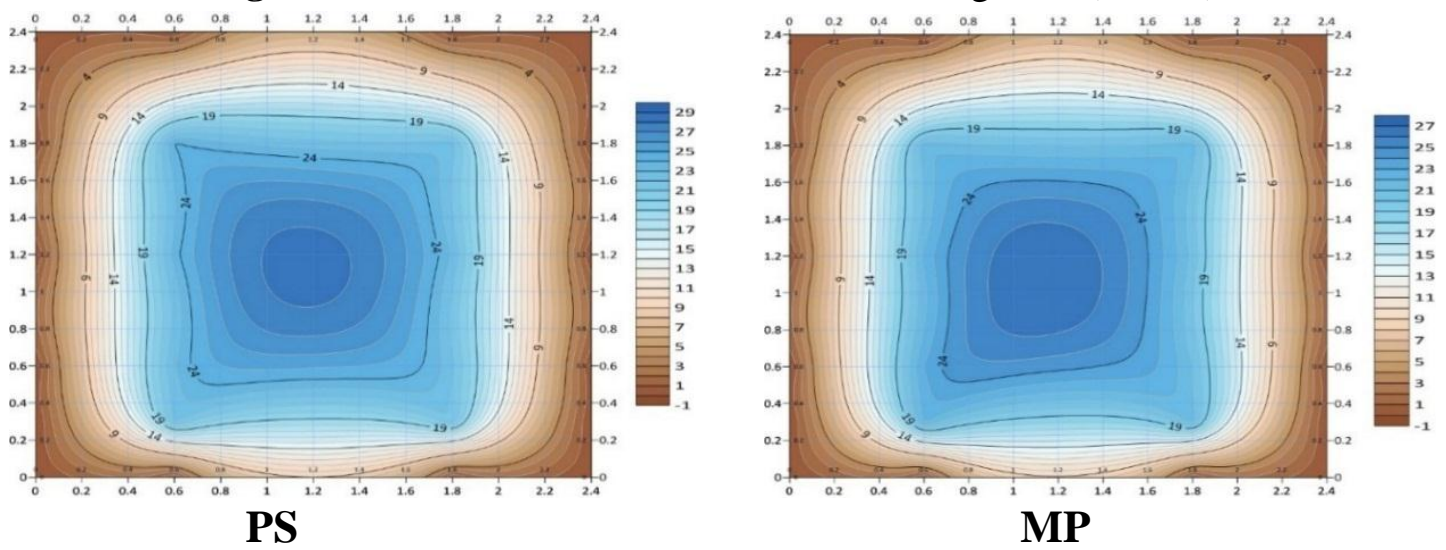

Fig (7): Soil moisture content after deficit irrigation (D60\%). 


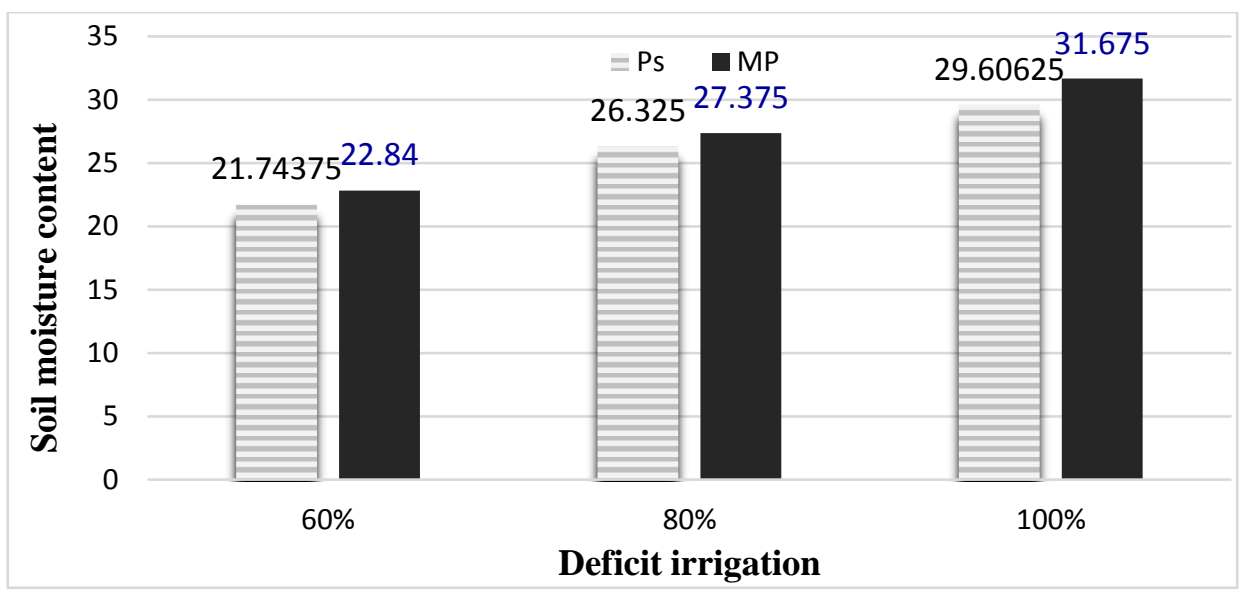

Fig (8): Average soil moisture content under deficit irrigation treatments.

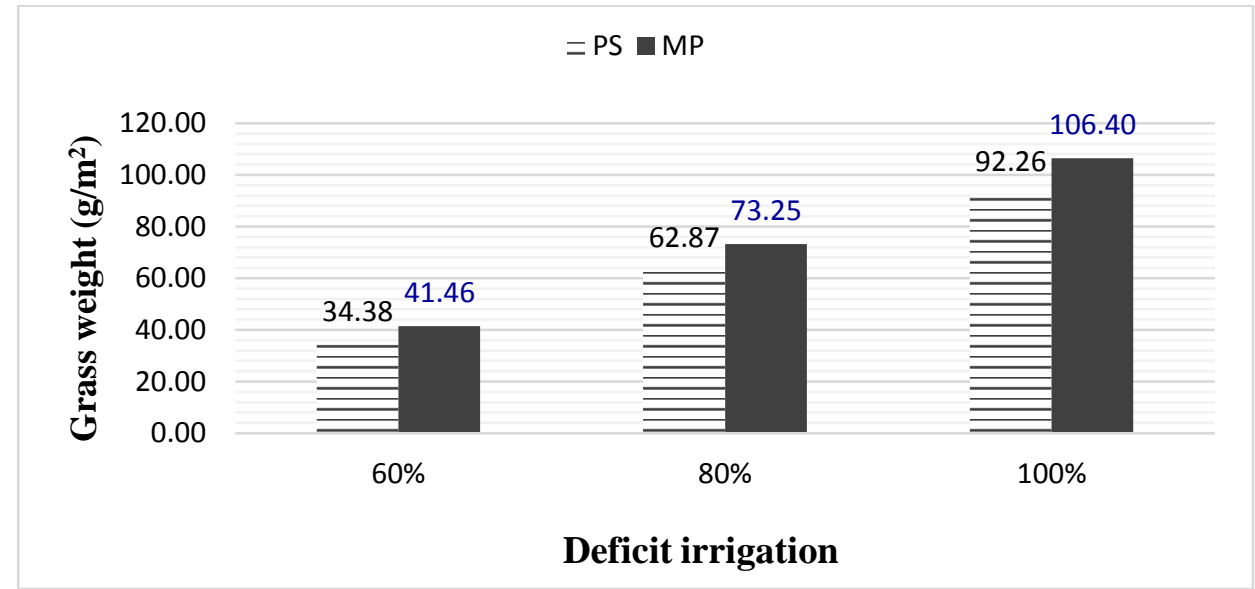

Fig (9): Grass growth weight for all irrigation levels.

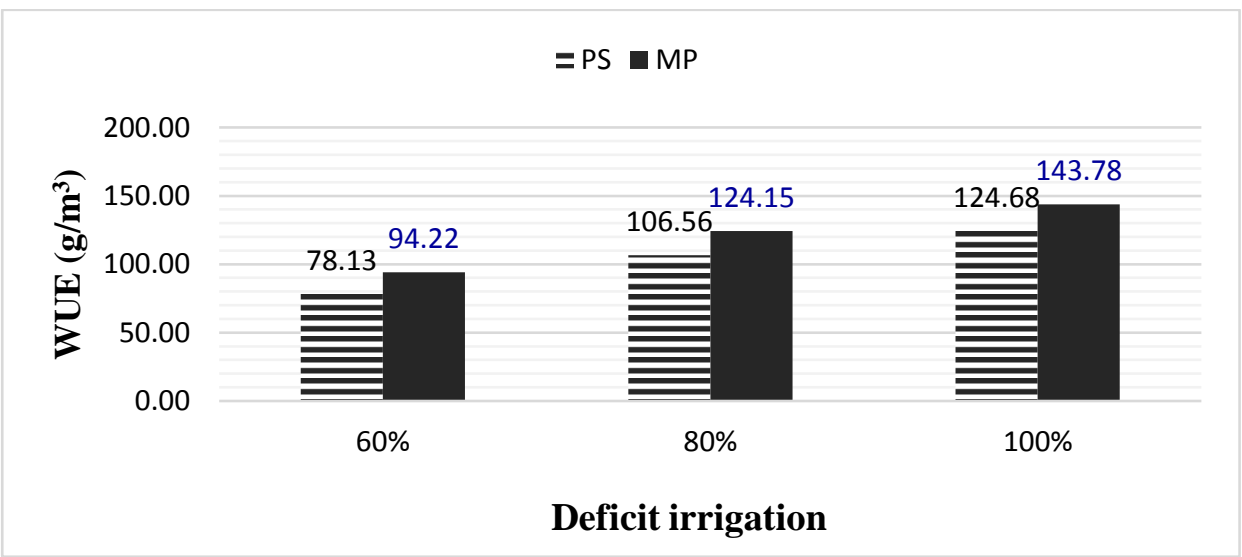

Fig (10): Water use efficiency for both sprinklers in all irrigation levels. 


\section{CONCLUSION}

It could be concluded that rotator sprinkler MP indicate better water distribution pattern, higher grass growth rate, water use efficiency, and less annual cost per square meter compared by sprayer PS. In other point of view, MP sprinkler can save $20 \%$ of irrigation water by applying $80 \%$ deficit irrigation without noticeable effect on grass growth and water use efficiency. The average water application rate for MP rotor sprinkler was about half that for PS sprayer, accordingly, the time of irrigation by using MP sprinkler was double of that by using PS sprayer. MP rotor sprinkler is preferred to use for sloping, and larger areas as well as in soils of less infiltration rate.

- MP sprinklers performance was better in the low quarter distribution uniformity $\left(D_{\mathrm{lq}}\right)$ than that of PS sprinklers and they were similar in coefficient of uniformity (CU).

- The average of soil moisture content for MP sprinkler after irrigation was higher than that for PS sprinkler.

- The growth rate of grass for MP sprinkler was higher than PS sprinkler in all deficit irrigation treatments.

\section{REFERENCES}

Ameer, K.H., Medan, S.A. And Hatfield, J. L. 2009. Effect of deficit irrigation and fertilization on cucumber. J. Agron 101(6): 15561564.

FAO. 1985. Irrigation Water Management: Training Manual No. 1 Introduction to Irrigation, Soil Bul. 55, FAO, Rome, Italy.

Huang, B. 2006. Turf grass water use and conservation strategies. Council for Agricultural Science and Technology (CAST). Water Quality and Quantity Issues for Turf grasses in Urban Landscapes. Pages 20:31.

Hunter, (2012), Irrigation Professionals with questions about design or comments concerning, Hunter Industries Incorporated, Book pages 52:61.

Ismael, S. 2009. Design and management of filed irrigation systems, Book. Pages 175:215 
Merriam, J.L. and Keller, J. 1978. Irrigation system evaluation: A Guide for Management. 3rd ed. Published by Agricultural and Irrigation Engineering Department, Utah State University, Logan, Utah. 271 p.

Sultan .W, M .Mustafa and A .Awwad. 2013. Evaluation techniques of garden irrigation systems on growth factors landscaping. Mansoura Univ. Vol.4. Pages 625:636.

Waltz C., and G. Wade 2007. Best Management Practices for Landscape Water Conservation: Introduction Chapter. 52 pgs.

\section{الملخص العربي : العي}

تقييم بعض رشاشات رى المسطحات الخضراء تحت مستويات رى مختلفة أحمد ر. عيد ' ، محمد ي.الأنصاري' ، أبوسريع أ. فرجّ و وائل م. سلطان؛

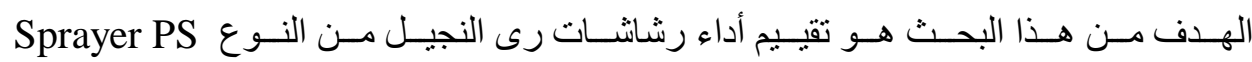

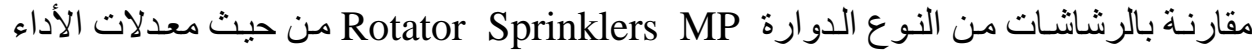

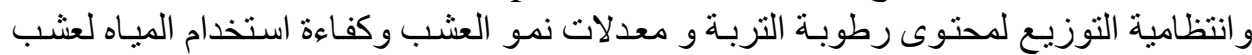

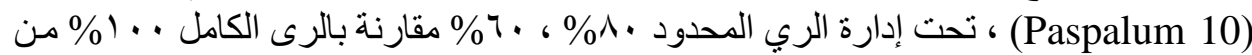

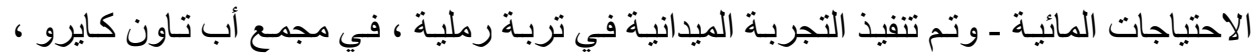

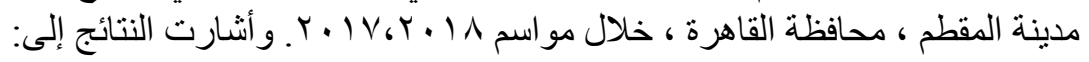

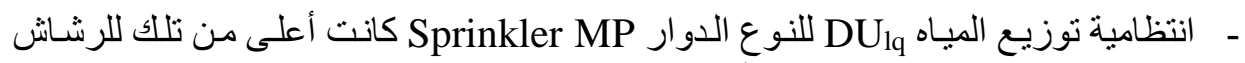
نوع PS ، في حين كان معامل الأنتظامية (CU) منشابهًا مع نوعي الرشانشات.

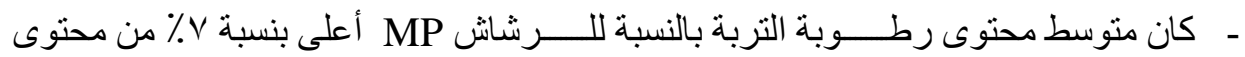
الرطوبة للرشاش PS في كل مستويات الري المحدود التي تم اختبار ها.

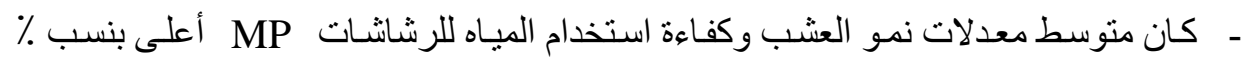

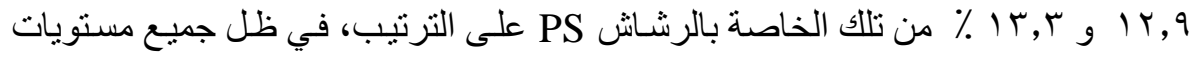
الري التي تم اختبار ها.

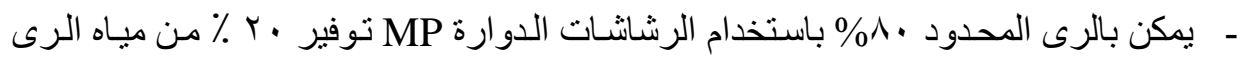

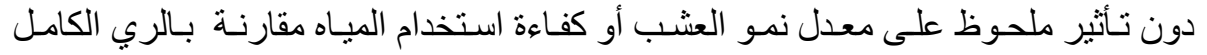

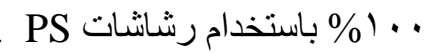

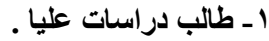

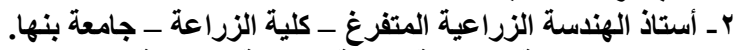

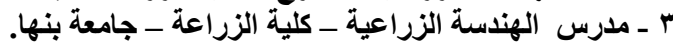

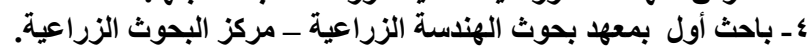

